\title{
The Flip Side: Women on the Redex Around Australia Reliability trials of the 1950s
}

\author{
Georgine Clarsen
}

In August 1953 almost 200 cars set off from the Sydney Showgrounds in what popular motoring histories have called the biggest, toughest, most ambitious, demanding, 'no-holds-barred' race, which 'caught the public imagination' and 'fuelled the nation with excitement'. ${ }^{1}$ It was the first Redex Around Australia Reliability Trial and organisers claimed it would be more testing than the famous Monte Carlo Rally through Europe and was the longest and most challenging motoring event since the New York-to-Paris race of $1908 .^{2}$ That 1953 field circuited the eastern half of the continent, travelling north via Brisbane, Mt Isa and Darwin, passing through Alice Springs to Adelaide and returning to the start point in Sydney via Melbourne. Two Redex trials followed, in 1954 and 1955, and each was longer and more demanding than the one before. The last two trials circled the entire continent to include Western Australia, returning to Sydney via Perth and the Nullarbor Plain. ${ }^{3}$

In an earlier article, I examined those Redex trials as a popular celebration of coming industrialisation and material prosperity, which articulated a range of possibilities for what it meant to be Australian in that postwar era. The trials offered a performative affirmation of the capacity of settler Australians to fully possess the continent through the power of modern technologies and provided a locus for popular debate about some of the meanings of Australian modernisation in those postwar years. ${ }^{4}$ This article focuses more closely on one element of that larger national conversation about how a modern automobile culture would find a particularly Australian expression by exploring women's engagements with the Redex trials. Women's unexpected and enthusiastic participation in the trials, their tremendous popularity with spectators, as well as their high profile

\footnotetext{
1 For accounts of the trials as motorsports events, see Tuckey, Bill and Floyd, Thomas B. 1979, Twenty-Five Years of Around Australia Trials: From Redex to Repco, Gregory's Publishing, Sydney, pp. 33-80; Tuckey, Bill 1989, The Wynns History of Famous Australian Car Trials, Golden Press, Sydney, pp. 18-48. See also the enthusiasts' web site: <http://www.uniquecarsandparts.com.au/redex_trials_the_legend.htm>

2 Daily Telegraph, 17 September 1953, p. 39.

3 Countless newspaper reports of the trials can be found on the dates surrounding each trial: 30 August - 12 September 1953; 3-20 July 1954; and 21 August - 11 September 1955.

4 Clarsen, Georgine 2010, 'Automobiles and Australian Modernisation: The Redex Around-Australia trials of the 1950s', Australian Historical Studies, vol. 41, no. 3, pp. 352-68.
} 
in media reports, provide new perspectives on the ways that automobiles were enmeshed in contestations over masculinity and femininity in Australia at that historical moment.

An around-Australia car race had been mooted since the 1930s, particularly to celebrate the sesquicentenary of British settlement in 1938, but it was not until 1953 that anything as ambitious was attempted. ${ }^{5}$ By then it was an idea whose time had arrived. As soon as the first trial was announced, the enthusiastic response from the public and the broad range of people who registered to enter the events caught even the organisers quite by surprise. That intense national fervour for around-Australia races was brief. By the end of the third trial, public interest in the events was evaporating and subsequent around-Australia reliability trials, such as the Ampol Trial of 1956 or the Mobilgas trials that followed, attracted much less national attention, barely registering beyond a circle of dedicated motorsport enthusiasts. ${ }^{6}$

For those three years, however, the Redex trials attracted extensive press coverage, as a burgeoning media network operating across multiple modes vied to bring stories and images to audiences across the country. Daily newspapers, motoring magazines, cinema newsreels, women's magazines such as the Australian Women's Weekly, popular publications such as Pix and Australasian Post, as well as nearreal-time reporting via hundreds of radio stations across Australia, reported in minute detail on the convoys of cars moving around the continent. Some media outlets, such as Sydney's Daily Telegraph, Brisbane's The Courier-Mail and the Women's Weekly, entered their own crews, while others followed the field in airplanes. ${ }^{7}$ Ken Hall of the Australian newsreel company Cinesound pre-sold film footage to trial entrants to help finance the documentaries he later distributed to national and international audiences. ${ }^{8}$ Media images showed battered cars covered in advertising slogans as dots on a vast landscape. Film footage featured cars careering around corners on two wheels, with funnels of dust suspended behind them, or surging across swollen creek beds, spectators standing by ready to push them through if they stalled. Photographs recorded wrecked and burnt-out cars strewn along desert tracks and exhausted crews in greasy overalls collapsed beside their vehicles in country showgrounds trying to snatch a few hours' sleep. Magazine covers featured competitors being hauled out of axle-

5 Hatfield, William 1937, Australia Through the Windscreen, Angus \& Robertson, Sydney; Argus, 11 July 1936, p. 25.

6 'What went wrong with the Redex?', Modern Motor, November 1955, pp. 14-26; 'The Redex Trial', Australian Motor Sports, October 1955, pp. 353-65.

7 Argus, 24 June 1954, p. 6.

8 The National Film and Sound Archive holds extensive newsreel footage of the Redex trials and has produced a compilation DVD: Redex Round Australia Car Trials (2004), \# 424021. 
deep mud by tractors or human muscle power, and there were countless images of the hundreds of thousands of spectators around the continent who lined roads all along the route to cheer the contestants on their way. ${ }^{9}$

Ostensibly, the Redex trials were about pitting family cars that were substantially the same as those available in dealers' showrooms against what were stated to be the worst road conditions in the world. Trial organisers, automobile manufacturers and their agents, as well as a plethora of spare-parts distributors, billed the trials as part of a rational project of technological advancement, a necessary element in producing tough cars especially suited to the harsh Australian conditions. Motoring associations, such as the National Roads and Motorists Association (NRMA) of New South Wales and the Royal Automobile Club of Victoria, used the trials to lobby for a greater proportion of petrol taxes to be allocated to road building. ${ }^{10}$ Newspaper editorials and petrol companies employed them to announce the arrival of the era of automobile tourism. ${ }^{11}$ The exuberance that surrounded the events, however, suggests that much more than rational considerations was at stake in these massed circuits of the continent.

Organisers had little experience in administering an event of that size and were forced to invent much of it as they went along. They worked hard to hold together the disparate elements of the contest and tried to keep a lid on some of the excesses. ${ }^{12}$ One of their main problems was to strike a balance between the interests of two very different types of competitors. On the one hand were private motorists who had entered in the 'spirit of adventure' and were driving their precious family car on a strictly limited budget. They wanted to return with their cars undamaged. On the other hand were manufacturers' teams with major commercial interests at stake, who were determined to win at any cost. Unlike private entrants who were forced to take their chances with finding fuel and mechanical help along the way, manufacturers' sponsored cars each year were given more technical support and detailed information about the route by dealerships around the continent. 'Serious' trial drivers complained that the 'inexperienced amateurs' turned the events into a mere 'tourist trip'. ${ }^{13}$ In addition to catering to the diversity of entrants, officials also needed to negotiate the conflicting demands of mounting a wild, exuberant event that would capture public attention - but one in which nobody would be killed, where the future of motoring in Australia would attract favourable press, and

9 Pix, 24 September 1955, Cover; 'Not for Sunday drivers', Newsreel clip, 1954 trial, Australianscreen, National Film and Sound Archive, Canberra, <http://aso.gov.au/titles/documentaries/1954-redex-trial/clip2/> 10 Broomham, Rosemary 1996, On the Road: The NRMA's first seventy-five years, Allen \& Unwin, Sydney, p. 107.

11 Daily Telegraph, 14 September 1953, p. 8.

12 'Redex review', Australian Motor Sports, August 1954, pp. 76-81.

13 Barrier Miner [Broken Hill], 14 July 1954, p. 3. 
where the traffic police would not close them down. ${ }^{14}$ Organisers optimistically declared that everyone who entered had a good chance of winning, or at least picking up some valuable prizes to help pay for the trip, but the tensions of the events were not easily resolved.

In hopeful words before the first trial, organisers outlined their conception:

A reliability trial is not a race and it is not an endurance test. The cars are such as can be bought at any showroom dealer. It is a sporting event in which the reliability of each competitor's car is the only consideration. Its point is in showing which car is more suitable for handling common road conditions than another.

Each section must be done in a set time, and fast driving is no guarantee that a competitor will do a section within a set time. Generally speaking, the earlier a competitor falls out the faster he has been speeding. Drivers must obey traffic regulations. ${ }^{15}$

Much closer to the truth, however, was motoring writer Evan Green's description. In his 1990 novel, Dust and Glory, he imagined what might have happened had there been a fourth Redex Trial in 1956. His hero, the much-loved larrikin rally driver 'Gelignite' Jack Murray, explains the event to an American rally driver, apparently used to a much tamer form of competition:

'What is a reliability trial?'

'A reliability trial is a mad bash over the roughest road you can find.'

'A mad bash?'

'Yeah. Flat out like a lizard down a drainpipe...It is a mad race. A wild event for the incurably insane. ${ }^{16}$

That description, rather than the official view, is largely how the events were represented at the time and how they continue to be remembered today. It was precisely the barely controlled anarchy of the original events that has resulted in the failure of successive re-enactments, regularly organised by car club enthusiasts, to reproduce the excitement of the original trials. In 1975, for example, two 'surviving veterans' of the first trial tried to revive the glory, but the motoring press of the day deemed it an abject failure:

14 'How to win the Redex Trial', Wheels, August 1955, pp. 6-9, 70; 'Redex trials', Open Road, 1 June 1955, p. 7.

15 Australian Motorist, August 1953, p. 16.

16 Green, Evan 1991, Dust and Glory, Pan Books, Sydney, pp. 12-14. 
Australia has changed...Instead of re-creating a rousing saga of tough, skilled men and hard-driven machines they merely made a sentimental journey backwards in time...Falling asleep from boredom was the major hazard... and the $67 \mathrm{~km} / \mathrm{h}$ required by the Redex between Alice and Adelaide is now almost too slow for old ladies... Their Peugeots returned undamaged; no part had been replaced. The drivers wore disappointment on their faces instead of battle-scars on their bodies. ${ }^{17}$

As such tame re-enactments suggest, what made the Redex trials so briefly successful as a national event that spoke to a mass audience was not just the fact of circling Australia in an automobile - that had first been accomplished in the mid-1920s and many times since - but rather the broader historical context that surrounded the events. ${ }^{18}$ It was the Redex trials' saturation in a particular historical moment that made them so memorable and loaded with significance for postwar Australians. These were not simply motorsports events, but were much more besides, and many of the themes that emerged in the press reports were only tangentially related to the challenge of racing a convoy of cars around Australia, three years in a row. This article argues that the Redex trials provided a vehicle for the expression of a disparate bundle of hopes and aspirations in those postwar years. As a touchstone for the mood of the nation, they offer a productive framework for a popular history of Australia in the mid-1950s that goes beyond the narrow concerns of standard motorsports histories.

Among the key non-motoring themes woven throughout media reports of the trials were images of a coming national life in which material prosperity promised to efface memories of the scarcities and restrictions that had characterised the two previous decades of economic depression and war. The trials unfolded as a coming-of-age story, a narrative of postwar optimism and abundance, in which Australia was finally to inherit its own (mini) industrial revolution. After 20 years of stagnation in car ownership, car registrations had returned to the rate of increase experienced in the boom years of the 1920s (Figure 1). ${ }^{19}$ Notably, by 1953 the first Australian production cars were beginning to enter the market in numbers and the trials demonstrated that they compared favourably with imported American, European and British cars. ${ }^{20}$ Images of 'Australia's own' Holden sedans careering along outback tracks generated enormous interest and

17 Browning, Michael 1975, 'The track winding back', Wheels, March, pp. 46-9, 81-2.

18 Davis, Pedr 1982-83, 'Trials and tribulations: great Australian car trials', This Australia, vol. 20, no. 1, pp. 15-24; Bishop, Peter 1998, 'Driving around: the unsettling of Australia', Studies in Travel Writing, vol. 2 (Spring), pp. 144-62; Clarsen, Georgine 1999, “Tracing the outline of nation": circling Australia by car', Continuum: Journal of Media and Cultural Studies, vol. 13, no. 3, pp. 359-436.

19 Knott, John 2000, “The conquering car": technology, symbolism and the motorisation of Australia before World War II', Australian Historical Studies, vol. 31, no. 114, pp. 1-26.

20 Loffler, Don 2008, Me and My Holden: A nostalgia trip with the early Holdens, Wakefield Press, Adelaide, Ch. 12. For an overview of the Australian motor industry, see Conlon, Robert and Perkins, John 2001, Wheels and Deals: The automotive industry in twentieth-century Australia, Ashgate, Aldershot, UK. 
national pride. They indicated a new industrial maturity for the nation, marking the moment when Australia climbed off the sheep's back and onto the grey motor of those early Holdens, thereby joining the rest of the industrialised world.

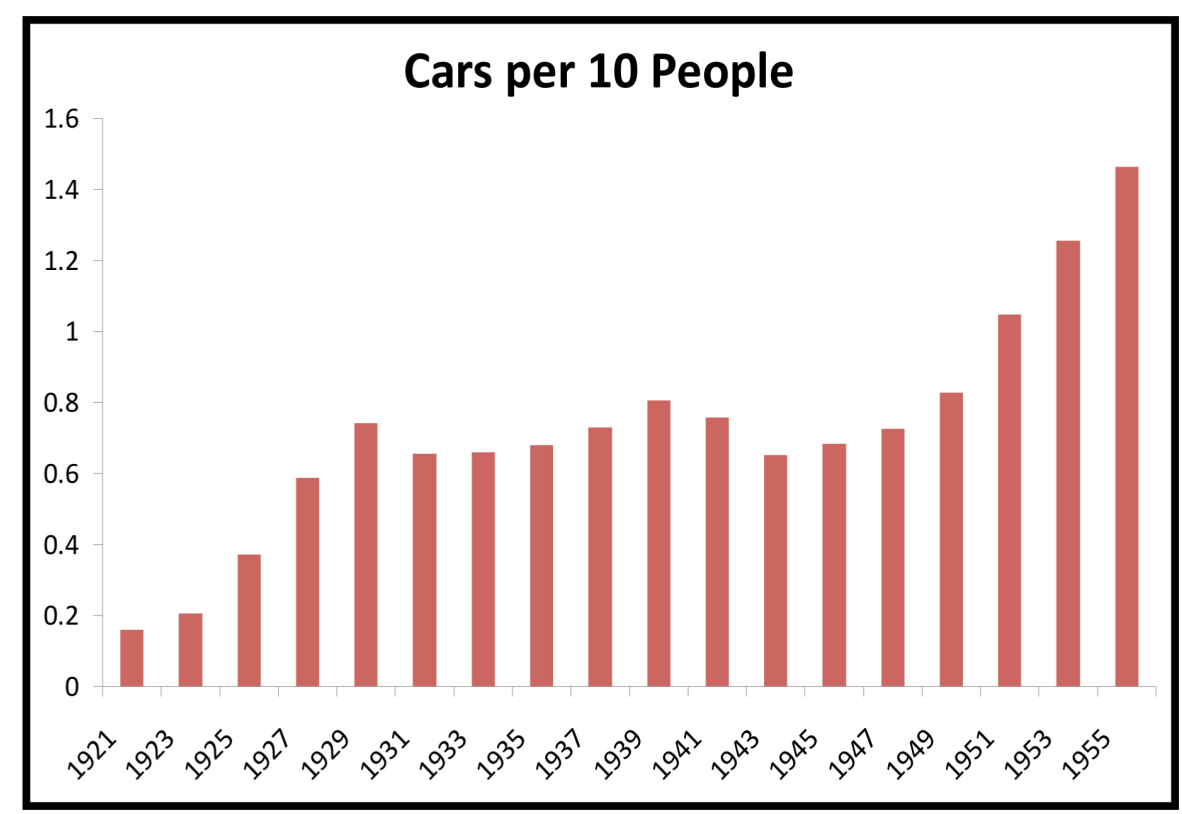

Figure 1 Motorcars and station wagons registered in Australia per 10 of population, 1921-55

Sources: Vamplew, Wray (ed.) 1987, Australian Historical Statistics, Fairfax, Syme and Weldon, Sydney, p. 171; and Australian Bureau of Statistics, Cat. no. 3105.0.65.001, Australian Historical Population Statistics, Table 2

The pleasure taken in the trials was not only about rising car ownership or the successful production of Australian automobiles, but was more broadly represented as a celebration of growing material abundance and conspicuous consumption. The events constituted a moment of excess in which, for the first time, Australians could enjoy watching (other people's) cars being destroyed. Automobiles no longer needed to be carefully hoarded and preserved, as they had been throughout the Depression and war, but in an expression of security about the solidity of postwar prosperity, they could be cheerfully and publicly wasted. Dramatic photographs in the print media and newsreel footage gleefully highlighted the destruction of and damage to competitors' cars. ${ }^{21}$ In the jocular spirit that characterised the reporting, teams at the rear of the field declared

21 'Up the East Coast', Newsreel clip, 1954 trial, Australianscreen, National Film and Sound Archive, Canberra, <http://aso.gov.au/titles/documentaries/1954-redex-trial/clipl> 
they did not need any official maps for navigation - all they needed to do was to follow the trail of hub caps, shattered windscreens, dropped luggage and the litter of wrecked cars along the route. ${ }^{22}$

Though the trials were billed as a celebration of coming Australian modernity, much of the imagery paradoxically promoted the kind of rough-and-ready masculinity that characterised the late nineteenth-century 'bush legend', as it was soon to be articulated by Russell Ward..$^{23}$ The dominant narratives of the Redex trials worked towards defining Australian motoring as a hyper-masculine enterprise in which physical endurance, strength and a bush mechanic's prowess were highly valued qualities. Far from projecting the smooth, sophisticated modernity that more often characterised European, British or American motoring in the postwar era, the Redex trials generated images of pre-modern masculinity. ${ }^{24}$ For three years, the graphic illustration used to represent the trials in the official Redex publicity showed a muscular, whip-cracking Roman gladiator astride a stripped-back automobile chassis. ${ }^{25}$ The persistence of such a pre-industrial, anti-modern image of modern Australian masculinity suggested some of the tensions and contradictions that accompanied the 'civilising' promises of technological developments, which threatened to erode traditional notions of the bodily foundations of male privilege. ${ }^{26}$ One of the best-loved and remembered characters of the Redex trials, for example, was 'Gelignite' Jack Murray, who was famous for detonating sticks of gelignite to confuse other competitors and annoy the police. Gelignite Jack was described as a '[g]leeful, prolific-swearing, teetotal, non-smoking, practical-joking, former amateur wrestling champion, pioneer water-skier and Bondi garage and taxi owner' ${ }^{27}$

Such representations of jocular and combative masculine resourcefulness confirm the arguments about masculinity and automobile culture put forward by a number of automobile historians. Clay McShane's and David Gartman's observations of early automobile consumption in the United States, Richard Strauss's narratives of masculine car culture in Australia during the 1970s and 1980s, as well as Paul Gilroy's analysis of African-American men's investments in conspicuous automobile consumption in recent decades, each suggest, in very different historical contexts, that the hyper-masculinist elements of car culture have offered men a vehicle of compensation for the perceived loss in status that

\footnotetext{
22 'Redex car in flames: seven others in race mishaps', Sun, 23 August 1955, p. 1.

23 Ward, Russell 1958, The Australian Legend, Oxford University Press, Melbourne.

24 Flink, James J. 1993, The Automobile Age, MIT Press, Cambridge, Mass., and London; Sachs, Wolfgang 1992, For Love of the Automobile: Looking back into the history of our desires, Don Reneau (trans.), University of California Press, Berkeley, Los Angeles and Oxford.

25 Wheels, October 1953, p. 424.

26 Forth, Christopher E. 2008, Masculinity in the Modern West: Gender, civilization and the body, Palgrave Macmillan, Basingstoke, UK.

27 Green, Evan 1966, Journeys with Gelignite Jack, Rigby, Sydney.
} 
accompanied changes in their working lives during the twentieth century. ${ }^{28}$ As new kinds of social organisation, dominated by corporate and industrial models of production - and in the African-American case by the added burden of systemic racism - came into play during the twentieth century, men turned to cars to recuperate their sense of lost masculinity. ${ }^{29}$ These scholars of automobility argue that cars have appealed to men's yearnings for physical hardship and personal autonomy and that the competitive elements of car culture offered a new field through which men could salvage notions of masculinity that rewarded brute force and physical domination. Cars, the argument goes, have served to offer men an emotional substitute for the perceived loss of status they attributed to modern economic and social change.

While those analyses tend to oversimplify the variety of masculinities that have characterised the twentieth century, as well as the plethora of car cultures through which those masculinities have been expressed, they do go some way towards setting the scene for women's secondary status as consumers of automobiles during much of the twentieth century. Since men quickly claimed automobiles as a prized masculine technology and presumed to define the terms under which cars would be adopted into social life, women motorists were obliged to exert a great deal of effort in order to be accepted as competent drivers, far beyond men of their race and class - their fathers, brothers, husbands and male friends. The very term 'woman driver' announced that they were supplementary to the main game. Time and again male judgment confidently declared that while men 'naturally' took to cars, the most that could be expected from women was a timid and uninformed response to machinery, rather than a relationship of mastery or ease with it. Wherever they turned, aspiring women motorists found transparently partisan definitions of automobile technology that worked to place them on the margins, even as they were invited to become consumers of it. ${ }^{30}$

During the 1950s and 1960s, Australian magazines and newspaper columns devoted to motoring emerged as sites for the elaboration of highly gendered meanings for automobiles. Targeted to a male audience, they worked to define cars as a quintessentially masculine technology and routinely denigrated women motorists, often through humorous stories or cartoons syndicated from the United States or Britain. There were numerous variations of 'wife at the wheel' jokes, in which women were depicted as reversing into fire hydrants, incapable of parking in the garage without running through the back wall, or using the

28 McShane, Clay 1994, Down the Asphalt Path: The automobile and the American city, Columbia University Press, New York; Gartman, David 1994, Auto Opium: A social history of American auto design, Routledge, New York; Strauss, Richard 1998, Up for Rego: A social history of the Holden Kingswood, Pluto Press, Sydney; Gilroy, Paul 2001, 'Driving while black', in Daniel Miller (ed.), Car Cultures, Berg, Oxford and New York, pp. 81-104. 29 For a more recent articulation of the masculinity of automobile technology, see Seiler, Cotton 2008, A Republic of Drivers: A cultural history of automobility in America, University of Chicago Press, Chicago.

30 Clarsen, Georgine 2008, Eat My Dust: Early women motorists, Johns Hopkins University Press, Baltimore. 
choke lever as a hook on which to hang their handbags. Young women drivers were frequently lampooned as ditzy, unable to concentrate on the task at hand or give a clear hand signal, and mothers-in-law were routinely portrayed as nagging back-seat drivers. ${ }^{31}$ The effect for aspiring women drivers was that even though the mechanical power of automobile technology promised to minimise the importance of organic bodily differences, and even though women were welcomed as consumers by automobile manufacturers, they were conscious of simultaneously being defined as trespassers on masculine territory. Women were obliged to do extra work to become motorists, beyond that required of male motorists. ${ }^{32}$ More than simply learning how to handle their cars, as men were invited to, women in those decades were also forced to compose their words and actions with an eye to the largely unwelcoming environment they encountered behind the steering wheel, under the bonnet and on the road.

It had not always been so, however, and the volume of popular ridicule towards women drivers that emerged in the 1950s was particular to that postwar era. During the 1910s and 1920s, when automobile ownership was largely confined to a privileged few, gendered disparagement of female drivers was more muted and some early women drivers even attracted public admiration. Until they were barred from competing against men, some women were respected and successful competitors on automobile and motorcycle racing circuits. ${ }^{33}$ In the post-World War I years, female motorists were frequently represented as quintessentially modern and adroit drivers and it was quite the thing for spirited young women to repair their own cars. Some women even established motor garages and were able to represent their businesses as the pinnacle of admirable female modernity. ${ }^{34}$ Only a decade before the Redex trials, during World War II, Australian magazines and newspapers published approving stories about women who were serving their country as motor transport drivers and mechanics in auxiliary military units. Having apparently forgotten the previous generation of women who worked in transport units during World War I and the female motor garages of the 1920s, press articles during World War II represented women's 'surprising' mechanical facility and their skill in driving even the heaviest trucks over long distances as novel developments. ${ }^{35}$ When

\footnotetext{
31 For some examples, see Wheels, June 1953, p. 64; September 1953, p. 342; November 1953, p. 506; March 1955, p. 64; April 1956, p. 50; June 1956, p. 68.

32 Davison, Graeme 2003, Car Wars: How the car won our hearts and conquered our cities, Angus \& Robertson, Sydney, Ch. 2.

33 Bouzanquet, Jean Francois 2009, Fast Ladies: Female racing drivers, 1888 to 1970, Veloce Publishing, Poundbury, Dorchester; Davis, S. C. H. 1955, Atalanta: Women as racing drivers, G. T. Foulis, London.

34 Clarsen, Georgine 2006, “"The woman who does"”: a Melbourne motor garage proprietor', in Laura Doan and Jane Garrity (eds), Sapphic Modernities: Sexuality, women and national culture, Palgrave Macmillan, New York, pp. 55-74.

35 For some press reports, see: 'Women learn to become mechanics', Argus, 25 November 1939, p. 12; Australian Women's Weekly, 1 June 1940, 5 October 1940, p. 31, 10 May 1941; Sydney Morning Herald, 31 July 1940; The Age, 18 February 1942 and 6 June 1942; Melbourne Herald, 6 February 1942; Melbourne Sun, 7 February 1942 and 18 February 1942; Australasian, 14 February 1942 and 28 February 1942.
} 
the war ended and motorcar ownership became more widespread, however, that public recognition of women's mechanical competence and driving skill was rapidly withdrawn. Stories of incompetent women motorists soon came to dominate public forums in the 1950s.

In spite of the marginalisation of women in the burgeoning postwar Australian car culture, the number of female drivers grew rapidly during the 1950s and women found ways to represent their activities in positive terms. ${ }^{36}$ Exservice drivers were particularly adept in developing strategies to resist their marginalisation. Women military transport drivers I interviewed during the 1990s remembered the public denigration of women drivers 40 years earlier, but privately continued to take immense pleasure in their mechanical capabilities and their wartime experiences of expanded mobility. ${ }^{37}$ Almost all of the women I interviewed were unable to find paid work that utilised their driving and mechanical skills when the war ended, though some remembered dearly wanting to do so. They recalled resenting the public ridicule of women drivers and retained their sense of competence by maintaining contacts with former members of their transport units. Most remained active drivers throughout their lives, sometimes servicing and maintaining their own cars into their old age. Ex-service drivers, such as Gwen Bagust of the 1954 trial and Enid Nunn and Nan Broughton of the Women's Weekly team, had driven ambulances with the Australian Women's Army Service. They were prominent among the female Redex entrants and were able to draw on their authority and experience as members of the transport units to articulate a legitimate place for themselves in the field.

Women who entered the Redex trials did so on terms that were different from men. Conscious of being in the public eye, they were forced to negotiate a fine line between definitions of the trials that marginalised their presence and yet not allow their own pleasure in the event to be spoilt. They had to secure the goodwill and cooperation of male officials and other competitors who were inclined to presume - even loudly declare - that women were 'out of place' on the trials and liable to find themselves in danger or constitute a hazard to others. They needed to defray their expenses by finding sponsors within a manufacturing sector that was sceptical of their talents and publicity value, and they had to avoid attracting the ire of the serious and aggressive competitors, who were impatient of any 'amateurs' who might slow them down. The result

36 The proportion of women drivers in Victoria was less than one in 10 during the 1950s, but by the end of the 1960s, more women than men were applying for driver's licences in that State, though far fewer women than men were registered car owners. Davison, Car Wars, pp. 28-30.

37 Clarsen, Georgine 1997, The vote on wheels: Australian women and motoring, 1915-1945, unpublished PhD thesis, University of Melbourne, Vic.; Staude, Lorna Staub 1989, Memoirs of an AWAS Driver, Naracoorte Herald Pty Ltd, Naracoorte, SA; Howard, Ann 1994, Where Do We Go From Here?, Tarka Publishing, Dangar Island, NSW; Ollif, Lorna 1981, Women in Khaki, Ollif Publishing, Sydney, Ch. 17. 
for women competitors was that they had to devise ways to put forward their own alternative definitions of and investments in the events. Some developed public styles that demonstrated a fine eye for the ironies of their positioning as less-than-welcome citizens of the road.

Some women entered as co-drivers or navigators in partnership with their husbands. They were generally assumed to be supplementary to the main game and, for the most part, it was only the women's press that wrote about them at any length. The Women's Weekly noted:

Husband and wife team, driving a Singer Nine, are Bill and Norma Williamson of Gerringong, NSW. Their car carries the Redex number 27 which tallies with the age of dark-haired, dark-eyed Norma Williamson, the mother of Allan (8 $\left.\frac{1}{2}\right)$, Bruce (7) and Christine (2 1/2). In 1953 and 1954 Mrs Williamson stayed at home with the children and listened to her husband's progress. This year she is taking her turn at the wheel and doing most of the navigating and food organizing. ${ }^{38}$

A few all-women teams entered the trials - for example, Stella Hall of Tamworth and her daughter, Wendy Matthews, entered the 1955 trial, declaring they intended to do all the mechanical work themselves. ${ }^{39}$ Such teams presented a challenge to the prevailing ethic of larrikin masculinity and the representation of women as adjuncts to their male partners. The only all-women team who entered the first Redex trial in 1953 - Lois and Nola Rowe and Diana Bruntonrepresented their preparedness and motives for joining the event with more than a touch of humour for their marginal positioning. Again, it was only the Women's Weekly that covered their inclusion in any detail:

The only all-woman team is determined to finish the course for the sake of the good name of women drivers everywhere. They are Sydney girls Lois and Nola Rowe, who are sisters, and Diana Brunton. They will drive a Sunbeam Talbot. Lois Rowe said that from two mechanics who work at the garage where their car is being overhauled they have learned to change tyres, put in new condensers and coils and clean the carburettor. 'If anything else goes wrong we'll just have to cross our fingers and hope for the best', she added. 'Nola is going to navigate for us. She hasn't had any navigating experience, but is just naturally good at finding the way'. ${ }^{40}$

38 Australian Women's Weekly, 24 August 1955, p. 35.

39 The Canberra Times, 21 May 1954, p. 2.

40 Australian Women's Weekly, 26 August 1953, pp. 27-9, and 16 September 1953, p. 20. The National Film and Sound Archive holds their home movie footage of the 1953 trial: \# 347419. 


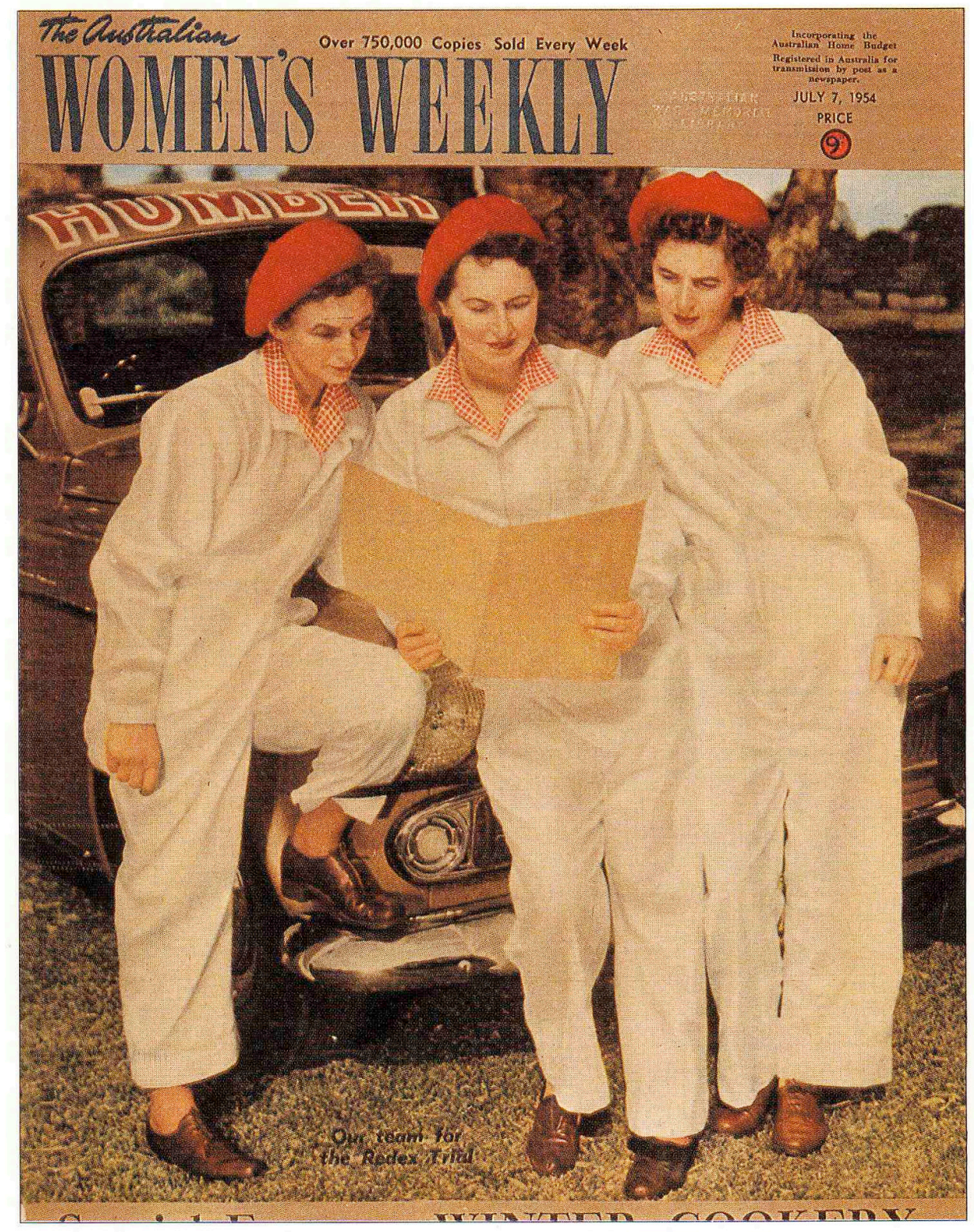

Figure 2 The Women's Weekly Crew, 1954. Cover image, The Australian Women's Weekly, 7 July 1954

Two members of the 1954 Women's Weekly crew, Enid Nunn and Nan Broughton, had been motor transport drivers during World War II. Their navigator and Women's Weekly journalist, Helen Frizell, a signaller during the war, called them 'expert drivers' and detailed their careful preparations with admiration - the clothes and food they had chosen, the preparation of their Humber Super Snipe, the windscreen washers, special map pockets and aircraft safety belts they had 
fitted, the de-ditching equipment, chains and spare parts they carried.$^{41}$ The women christened their car 'Narda', the heroine in the Mandrake comic strip published by the Women's Weekly, for her survival skills against all odds. They were the only all-women team to finish in the 1954 trial. A Women's Weekly team again entered in the 1955 trial, that time driving the latest turquoise and white Holden business sedan, but like many competitors were forced to withdraw before the Port Hedland checkpoint because of the rough terrain and punishing schedule. ${ }^{42}$

The Women's Weekly covered the trials in great detail and featured the crew and their cars on the front cover of the magazine before the trials began. They were mobbed by women all around the country, who waved their 'Redex Cover Girl' copies of the Women's Weekly and requested autographs. Fans threw fruit into the women's cars, garlanded them with flowers, sent encouraging telegrams, and lined the route, shouting, 'Come on Narda'. A male crew that followed them in the trial named their car 'Mandrake' and another became known as 'Lothar'. Like other women competitors, the Women's Weekly team announced they were content just to finish with their car intact. They were careful to maintain the goodwill of the rest of the field and keep out of the way of the serious contenders:

The attitude of men towards our all-women crew was excellent, considering there were plenty of opportunities on the trial for ordinary courtesy to wear thin as the weary miles piled up behind competitors and the strain became greater...We deliberately kept to a slower pace than the men so we usually did most of the pulling aside to let them pass. Nor did we ask for any help along the road, but if [it] was offered we appreciated that. ${ }^{43}$

As with the Rowe sisters in the first trial, in Helen Frizell's stories, the practicalities of what the Women's Weekly crew should wear, where they would sleep, and how often they might get to bathe played an important part. The reports she filed stood in marked contrast with the bush-bashing ethic more common in the general press and men's magazines, depicting women as engaged in a rather different enterprise. Frizell's stories focused less on automobiles as modern tools for 'conquering' hostile terrain, reporting instead on the benefits they could bring to life in the 'outback'. She wrote of the hospitality they met in the bush, the lonely life of outback women, beautiful wildflowers, iconic landscapes and 'shy Aboriginal children and their mothers [who] hung around the whole time we were there, gazing at the hive of activity caused by the trial drivers' ${ }^{44}$ The sources of Frizell's imagery stood in marked contrast with the

41 Australian Women's Weekly, 23 June 1954, p. 17, and 7 July 1954.

42 Ibid., 14 September 1955, pp. 20-1.

43 Ibid., 28 July 1954, p. 20.

44 Ibid., 21 July 1954, pp. 20-1, and 28 July 1954, pp. 20-1. 
inspiration for male reporters' accounts. Of the conditions they found in the Top End, she wrote, 'Yes it was the dust we had heard so much about - the colour of cocoa finely sifted as if by a housewife making a giant chocolate cake...[it] soon turned us all into the colour of Red Indians' ${ }^{45}$ The following year, she described the mud they encountered as 'about the consistency of chocolate blanc-mange' ${ }^{46}$ Frizell's imagery points to a 1950s, feminine version of the persistent urban Australian fascination with the 'back of beyond' of European settlement - the 'bush', the 'outback' or the 'never-never' ${ }^{47}$ She articulated a homely and domesticated orientation to those places that few urban women were able to visit.

It seems that some of the female entrants best situated to resist their marginalisation within the masculine climate of the trials, and even turn it into a publicly applauded stance, were older women of independent means who remembered a more honourable past for women motorists. These 'Grannies of the trials' were taken up as popular heroines and generated tremendous public attention-and not only in the women's press. Sixty-five-year-old Mrs Charlotte Hayes of Glebe, who told the press she was 'as strong as a horse', captured considerable media coverage when she entered her Volkswagen in the 1955 trial, with her son and his friend as her navigator and mechanic. ${ }^{48}$ It was Mrs Winifred Conway of Rose Bay, who entered the 1953 and 1954 trials in her modest Austin A40, however, who emerged as one of the best-loved entrants. The press dubbed her 'the most popular contestant' and the 'Granny who stole the limelight'. ${ }^{49}$ The progress of Conway, a widow who gained her licence in 1913, around the continent attracted front-page coverage in daily newspapers and she soon demonstrated a fine talent for supplying reporters with an irresistible quote. Her Redex career did not start auspiciously, however, and she declared that her small convertible touring car, which had done 24000 miles $(19000 \mathrm{~km})$ before the event started, was 'probably the most unwanted car in the trial'.$^{50}$

Winifred Conway chose a former army driver, Margaret Bruce, as co-driver and navigator for the 1953 trial and advertised to find a male driver, Denys Tanner, to accompany them. ${ }^{51}$ She declared she had been forced to make about 100 phone calls before she managed to secure some minor sponsors to support her entry. Eventually, she found backing from a manufacturer of hoods, a brake

45 Ibid., 21 July 1954, p. 20.

46 Ibid., 17 August 1955, p. 13.

47 McGrath, Ann 1991, 'Travels to a distant past: the mythology of the outback', Australian Cultural

History, vol. 10, pp. 113-23.

48 Australian Women's Weekly, 24 August 1955, p. 35.

49 Sydney Morning Herald, 12 September 1953, p. 1, and 20 September 1953, p. 9.

50 Australian Women's Weekly, 23 September 1953, p. 20.

51 Daily Telegraph, 13 September 1953, p. 5. 
company, a respray firm which offered to repair any damage to the paintwork, and the Jubilee tobacco company, which painted 'Ready rubbed, extra fine cut' behind the driver's door.

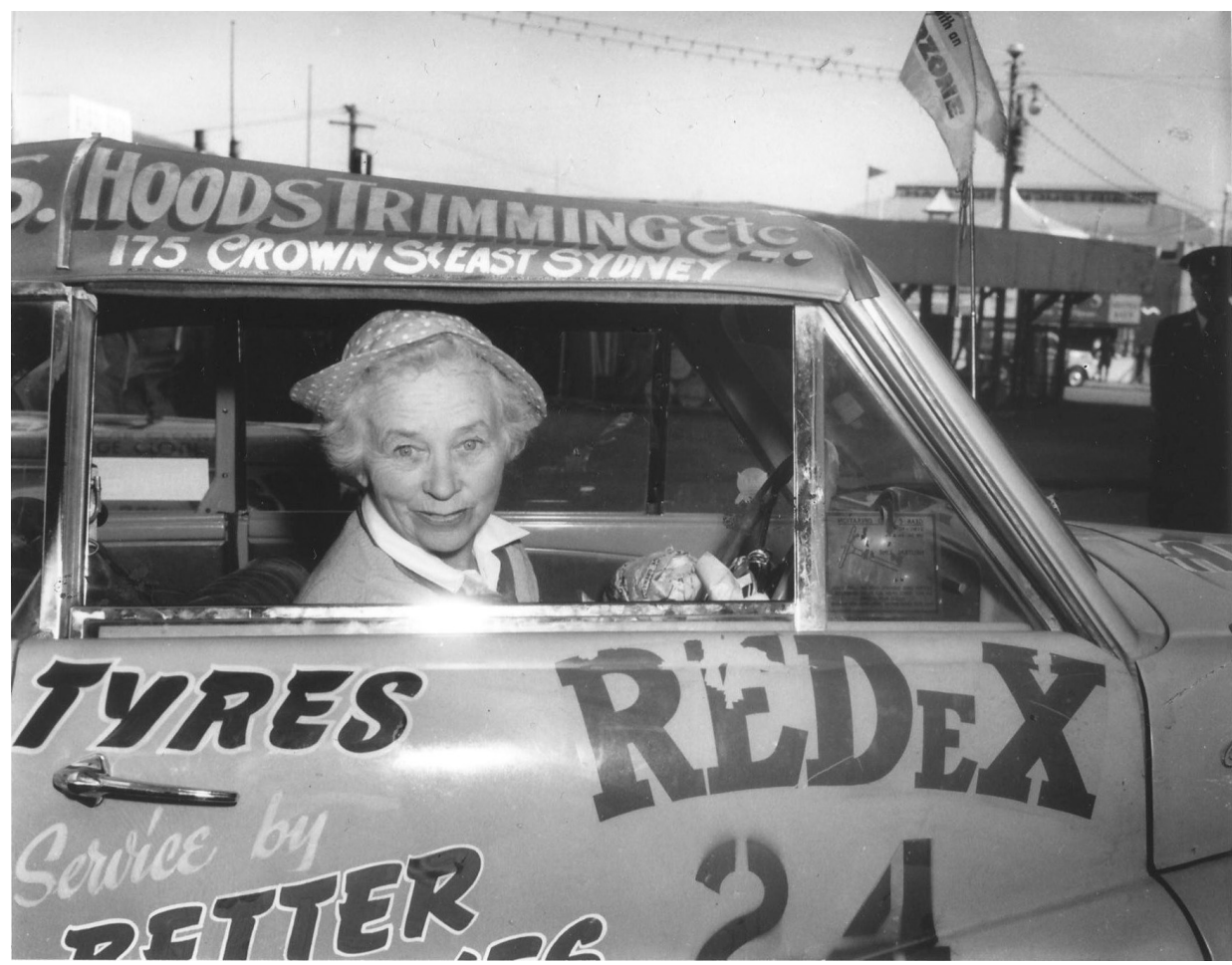

Figure 3 Winifred Conway in the 1954 trial

Courtesy of the Ford Discovery Centre, Geelong, Victoria

When Conway approached the Sydney Austin dealer Larke Hoskins to officially sponsor her in the first trial, they spurned her request. 'They told me they had already sponsored two teams, that the roads were too rough for a woman of my age and that I was mad', she told the Woman's Weekly. ${ }^{52}$ So angry was Conway about her rejection by the Austin dealer that for the early part of the trial, she declared she was driving a Monarch from Germany - an entirely fictitious make. Other male commentators loudly endorsed the dealer's views. Experienced rally driver Lex Davison and the prominent journalist and author Douglas Lockwood similarly declared that the trials were no place for grandmothers like Winifred Conway. She responded by declaring that men and women would be on the same footing throughout the trials and that 'an experienced woman driver is just as good as a man'. ${ }^{53}$

52 Australian Women's Weekly, 23 September 1953, p. 20.

53 The Courier-Mail, 17 May 1954, p. 3. 
What secured Winifred Conway's popularity was not just her motoring confidence, but also her wit and vitality, her impeccable grooming, her sweet demeanour, and her apparent disregard for the combative ethic that characterised the trials. She always drove in hat and white gloves and delighted her fans when she turned up at the finish line with a fresh blue rinse. Conway first attracted national attention in 1953 when, arriving late at the Rockhampton checkpoint due to rough roads and bad weather, she told the press that she did not mind, as she was only competing for the prize of the automatic pop-up toaster offered to the best Austin entrant. She wanted to see the country, talk to strangers, have picnics, take photos and enjoy herself, she frequently announced. ${ }^{54}$ It was a holiday, she told the press, 'the best rest I've ever had-no one to look after'. Conway kissed as many spectators as she could, signed hundreds of autographs and displayed a blithe indifference for the mechanical gravity of the event: 'I am not worried about the car, it will look after itself', she said. 'My motto is never touch the engine. You always strike trouble when you start lifting the bonnet.'55

By the end of the 1953 trial, the Austin dealers had reversed their thinking entirely. Even though one of their sponsored entrants finished in the top 10 and Conway somewhere in the middle of the field, it was Mrs Conway- the 'Galloping Grandma' — who had garnered by far the greatest publicity for their product. Larke Hoskins placed full-page advertisements in the daily press to promote her successful return. ${ }^{56}$ They hosted receptions for her, which attracted crowds of admiring women, and displayed her battered car in their William Street showroom. With great ceremony, they presented 'Nannie Conway' with the newest model Austin A40 convertible sedan. Conway won even more fans when she selected - contrary to her grandchildren's advice - a racy convertible coupe instead of the staid sedan. It was the car of choice for film stars and millionaires, she declared. ${ }^{57}$ Though she had not been the best Austin entrant, at the end of the trial, Conway was presented with three automatic toastersdonated by the Woman's Weekly, the Redex organisers and Larke Hoskins-as well as a gold watch set with sapphires and rubies.

Dame Enid Lyons, the retired politician who had become a popular newspaper columnist, was one of Winifred Conway's prominent admirers. Lyons declared her indignation at the 'withering' male comments about women such as Granny Conway 'cluttering up the contest' and declared that her 'heart had been with the grannies from the start' ${ }^{58}$ Conway became a favoured figure in advertisements for a variety of products. A paint company used images of her on a ladder painting her house ('It's lots easier to paint a room a day than drive

\footnotetext{
Sunday Telegraph, 6 September 1953, p. 5; Australian Women's Weekly, 16 September 1953, p. 23. 
500 miles a day'), a sewing machine company featured images of her beside her car with their portable machine ('She sews as she goes with a Singer') and department stores around the country put her car in their display windows and hired her to give lectures to other women on her motoring experiences. ${ }^{59}$ Conway was inundated with fan mail from readers from all over Australia, who simply addressed their letters to 'Granny Conway' and 'the Super Woman'.

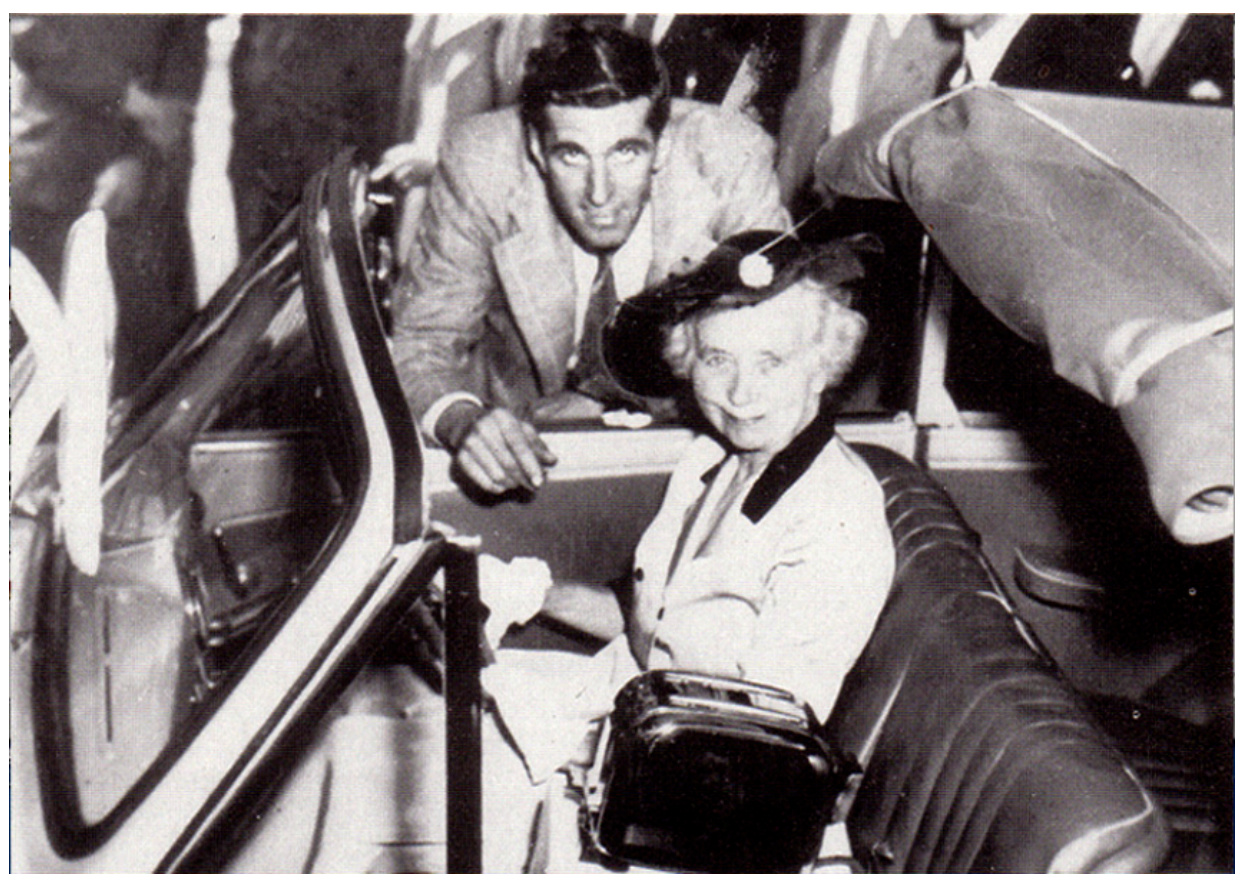

Figure 4 Winifred Conway's triumph in the 1953 trial

Photograph courtesy of Hal Moloney

Such triumphs claimed by women entrants were, of course, far from the preindustrial, gladiatorial style displayed by the male heroes of the trials - be they winners, such as Jack Murray, or magnificent losers such as Ken Wilson, whose numerous accidents and endless mechanical disasters attracted a great deal of press attention. ${ }^{60}$ Reports of women entrants articulated distinctly different concerns and pleasures, placing them on another kind of trial altogether. Edith Nielson, a widow from Brighton-le-Sands in Sydney and a keen amateur photographer, for example, stated that she entered the 1954 trial with the aim of making a colour film of her experience. She hoped to have the film screened in Canada, where a relative owned a chain of cinemas, as 'unofficial publicity for

59 Sydney Morning Herald, 19 September 1953, p. 4, and 24 July 1954, p. 7; The Advertiser [Adelaide], 8 October 1953, p. 4.

60 Daily Telegraph, 29 August 1953; Wheels, October 1953, pp. 378-90. 
Australia'. Her driving partner, the ex-servicewoman Gwen Bagust, said, 'I'm going on this trip because it's a wonderful chance to see parts of Australia that most tourists miss' ${ }^{61}$ Such women were engaged in a representational project that spoke to alternative modernist yearnings. Rather than the romance of a physically arduous and testing past, they articulated a vision of the future in which new technologies could make it easier for women to take part in projects and pleasures that had previously been denied to them.

Of all the female entrants, it was Winifred Conway who most forcefully expressed what the trials meant to her:

For years I have wanted to drive to Darwin and through Central Australia, but I was too afraid to go alone. I realised I would be perfectly safe on this trial, as the other drivers would provide a wonderful escort. As I mainly wished to see the country, take photos and enjoy myself, I have not worried about losing points. We have had picnics on the way. ${ }^{62}$

At the same time as expressing her pleasure in the event, Winifred Conway adopted a critical stance towards the competitive ethic that dominated the trials. Implicit in her statements to the press was a particular view of the value of automobiles. She articulated a definition of the meaning of cars - what they were useful for, how they might be brought into social life, and the proper relationships that should obtain between them and their users - that was rarely expressed in the context of the Redex trials. It was a view that did not always endear her to male competitors. She spoke out plainly against what she perceived as the irrational approach to automobile technology adopted by male competitors and stoutly justified her cautious driving style. Unlike the rest of the field, she claimed, she drove at no more than $60 \mathrm{~m} / \mathrm{h}(95 \mathrm{~km} / \mathrm{h})$ and her car responded well to that treatment. It 'went like a camel' through the desert, she declared, was economical on petrol, used very little oil or water, and arrived at the finish line without a scratch. Her assessment of the shortcomings of other drivers was blunt and to the point: 'Drivers who skidded off the road, overturned their cars, or otherwise came to grief, did so mostly because of the high speeds at which they were travelling. ${ }^{63}$

Conway loved to repeat that she never 'meddled' with her engine, though she asserted that if anything went wrong she was able to identify the problem. She was scornful of the many hours that male competitors spent in garages 'tinkering' with their cars to prepare them for the next section. Instead of driving at high speeds so that they could get to the next checkpoint early to fix their cars, she declared, it would have been wiser for them to drive more carefully so those

61 Undated newspaper clipping in Hugh King's collection.

62 Sydney Morning Herald, 12 September 1953, p. 1. 
repairs were not needed in the first place. 'Men should have more confidence in the engineers who build cars', she said. 'Leave it to the makers, they know what they are doing - that's my maxim.' ${ }^{64}$ Winifred Conway's vision of automobile technology, which she characterised as properly composed of non-expert male and female users and expert male professionals, anticipated the car culture that gradually emerged throughout the twentieth century. As the technology became more reliable and automatically controlled, leaving fewer functions in the hands of drivers, 'tinkering' was increasingly discouraged, so that car owners came to risk losing their warranty if someone other than an authorised dealer serviced their car.

For Conway, a single middle-class woman of independent means, the prospect of mass automobile technology that was underpinned by professional male expertise had the potential to efface some of the limitations imposed on her. Car consumption promised to reduce the salience of sexual differences. It afforded personal security in public spaces and offered hope of addressing the unequal ways of moving that had acted as a constraint on her independent travel in the past. Conway's statements to the press envisioned her car as something of a mobile living room in which she was able to safely journey from the privacy of her house into the daunting spaces of the Australian outback. A semi-private space in a public domain, her car allowed her to be at home on the road and she revelled in the new forms of sociality it enabled. Her forthright pronouncements on automobiles as a site of contestation between men and women - taken up and amplified by the press - struck a chord within national debates. Conway was widely admired for the deft touch she displayed as she staked her claim in that struggle, where both the meanings of automobiles and the notions of gender were at stake.

By placing women's expression of their investments and interests in the Redex trials at the centre, rather than accepting standard masculine definitions of the events as the norm, this article locates both gender and automobiles as social categories in relation. It explores the ways that the meanings of both automobiles and gender are specific to their moment, always contested and thereby subject to change. While the dominant definitions of the trials sought to import earlier versions of heroic masculinity into the automobile era, recuperating ideals of male physical domination and prowess within a technology that was promising to efface those differences, women competitors and significant proportions of the national audience articulated another view. Winifred Conway and other women who took part in the trials put forward alternative modernist ideals. They were able to shape those high-profile national events in ways that could answer to their dreams of a more inclusive, comfortable and convivial future, 
in which the technological innovations of twentieth-century modernity could provide them with new powers and new experiences. For them, the pleasure of an automatic pop-up toaster could be its own reward.

\section{Acknowledgment}

I would like to acknowledge the generosity of Hal Moloney and Hugh King, who kindly gave me access to their files and extensive knowledge of the Redex trials. 